\title{
The Phenomenological Act of Perscrutatio in the Proemium of St. B onaventure's Commentary on the Sentences
}

\author{
EMMANUEL FALQUE
}

Catholic Institute of Paris*

\section{(translated from the French by ELISA MANGINA)}

As Hans Urs von Balthasar has put it, "nothing is more typical of [St. Bonaventure] than the prologue to the whole commentary on the Sentences." 1 This remark is the inspiration for the following rereading of Bonaventure's inaugural lecture. Not only does the Commentary succeed to a remarkable degree in unifying scholasticism and mysticism, but it also contains the seeds of a descriptive theological method that is original in ways that parallel contemporary phenomenological thought, despite the risk of anachronism inherent in such a claim.

Profunda fluviorum scrutatus est, et abscondita produxit in lucem (Job 28:11). 2 This verse from the Book of Job, with which Bonaventure opens his Proemium, should be interpreted first as a "a crystalization of all that constitutes the significance of theology," that is, a searching of the depths and a bringing of hidden things to light. $3 \mathrm{O}$ the one hand, then, we have the hiding place of the mytery that remains veiled in the four books of the Sentences (the rivers of the Trinity, creation, the Incarnation, and the sacraments). On the other hand, we have the theologian's role sanctified-or, better, consecrated-by the Holy Spirit as a "searcher of secrets and of the depths" ( perscrutator secretorum et profundorum), a formulation that explicitly

*Most recent publication: Saint Bonaventure et I' entré de Dieu en theologie, La Somme théologique du Breviloquium (prologue et premiere partie), coll. "Etudes de philosophie médiévale," (Paris: Vrin, 2000).

1. Hans Urs von Balthasar, The Glory of the L ord: A Theological A esthetics, vol. II: Studies in Theological Style: Clerical Styles, trans. Andrew Louth, Francis McDonagh, and Brian McNeil, C.R.V. (San Francisco: I gnatius Press, 1984), p. 264.

2. Bonaventure, Sent. proem. $(I, 1)$. All references to the Proemium of the Senten ces refer to the Quarrachi edition, 1882-1902, O pera omnia, 10 vols. in folio, 1:1-15.

3. A. Ménard, "Une leçon inaugurale de Bonaventure, le Proemium du Livre des Sentences," Études franciscaines XXI, vol. 59, 1971, p. 276. 


\section{EMMANUEL FALQUE}

takes its cue from the pneumatological imperative of 1 Corinthians: Spiritus omnia perscrutatur, etiam profunda Dei (1 Cor. 2:10). 4

Thus, at the beginning of his Commentary, Bonaventure defines (1) the subject matter, or material cause, of the Senten ces; (2) its specific method, or formal cause; ( 3 ) its deliberate intention, or final cause; and (4) its author, or efficient cause. He departs from other bachelors of the Sentences in combining two interpretations, one symbolic and the other scholastic. This innovation seems even more radical to us insofar as it exemplifies, without separating them, the two great dimensions of Bonaventure's discourse: symbolism, exemplified in the prologue of the Proemium, and scholastic form, exemplified in the Proemium's quaestiones. 5 In order to illustrate this specifically Bonaventuran tendency to correlate and unify the free play of the symbolic with the order of the scholastic, one need only compare the proemium of Bonaventure's Commentary on the Sentences with the prologus to Aquinas's Commentary, written shortly after Bonaventure's. Although Thomas takes as the epigraph to his prologue the famous verse from Ecclesiasticus on the symbolism of the river (Vulgate, Eccl. 24:40), nowhere in his discussion does he offer an exegesis of it. This omission is almost certainly deliberate. Similarly, Thomas almost nowhere uses the verse from Job (Job 28:11) that Bonaventure makes the epigraph to his prologue. As we shall see, the "searching of the rivers' depths" (profunda fluviorum sratatus est) and the "bringing of hidden things to light" (abscondita produxit in lucem) define Bonaventure's theological method of perscrutatio as "penetrating" or "unveiling." Yet this verse, with its new but often overlooked methodological imperatives, appears in Aquinas's work as only one among many texts used to define theology's matter. Thomas never uses it on its own.

For Thomas, the reference to Scripture has become a mere school exercise and the occasion for a purely scholastic four-part division of theology (manifestatio/ productio/ restauratio/ perfectio). For Bonaventure, by contrast, it is always the unique source of the entire discourse as well as of its structure. In other words, even if the theological partition (Trinity/ creation/ Incarnation/ sacraments and resurrection) remains the same for both

Thomas and Bonaventure, as a reading of the Sentences requires, the melody that it produces differs completely from one to the other. Whereas the Angelic Doctor deliberately ignores the biblical symbolism of the four rivers (Pishon, Gihon, Tigris, and Euphrates), the Seraphic Doctor uses it for the very structure of his argument and even of his theology itself. 6

4. Sent. proem. $(1,5)$.

5. Sent. proem. (I, 1-6), the symbolic interpretation; Sent. quaest. proem. q. 1-4 $(1,6-15)$, the scholastic interpretation.

6. For the prologus of St. Thomas Aquinas's Commentary on the Sentences, see Sancti Thomae Aquinatis commentum in primum librum sententiarum magistri Petri Lombardi, Editio nova, R. P. Mandonnet (Paris: Lethielleux, 1929), pp. 1-5 (prol. S. Thomae) and 6-19 (quaest. prol.). The epigraph is from Ecclesiasticus (p. 1), with an unattributed quotation from the passage from Job (p. 2). 
Part of the originality of Bonaventure's prologue lies in its historical location on the boundary between symbolic and scholastic interpretations. Moreover, his entire system of thought draws its force so completely from this interplay that he identifies the expository method he finds in the Sentences with the principles of theology itself: quae sit materia quodve subiectum huius libri vel theologiae. ${ }^{7}$ This testifies to the extent to which Bonaventure's inaugural lecture, along with the methodological principles it contains, establishes itself as the seed or premise of all the theological developments to follow. And although the difference between the symbolic and scholastic readings is accompanied by a difference in the treatment of questions (one might here compare the expository styles of the I tinerarium and the Breviloquium), there is no place in Bonaventure's works where they feed off one another more than they do here. In other words, their enriching of one another in this proemium, which is paradigmatic for all of Bonaventure's works, is such that the mystic's rich symbolism (proemium) and the theologian's scholastic formalism (quaestiones proemii) first blend together in an indissoluble, exemplary unity.

Thus, I will argue that the originality of Bonaventure's theological method can be seen at the heart of this reading of theology in accordance with its four causes-a classic hermeneutical move in the Middle Ages. Specifically, the originality of his method consists in the four ways it links the symbolic and the scholastic:

(1). Bonaventure makes the scholastic determination of theology's subiectum ("God as a radical principle, a completely integral Christ, and the universal relationship between object and sign" [1, 6-8]) correspond to the symbol for theology's material cause the four rivers ( "of the divine emanation" [Pishon], of created things [Gihon], of Incarnation [Tigris], and of sacramental economy [Euphrates] [I, 1-3]).

(2). Bonaventure links the different scholastic theological modes ("confounding one's adversaries, strengthening the weak, and giving to the righteous the gift of loving with their intelligence what they believe by faith" [I, 9-11]) with the symbol for theology's formal cause the river's depth ( "the sublimity [ of the Trinitarian God], the emptiness [ of created things], the merit [of the Incarnation], the efficacy [of the sacraments]" [1, 3-4]).

(3). He connects the scholastic determination of theology as "an affective disposition" (habitus affectivus) midway between the speculative and practical ("the primacy of practical over speculative theology" [I, 12-13]) with the symbol for theology's final cause: the revealing of what lies hidden in God ("greatness [ the divine substance], order [ the wisdom hidden in creatures], power [the humility of Christ on the cross], and sweetness [ mercy in the sacraments]" [I, 4-6]).

(4). Bonaventure juxtaposes the eminently scholastic figure of Peter

7. Sent. quaest. proem., q. $1(I, 6)$ : the statement of the question. 
Lombard, the author (auctor) of the Book of Sentences ("not only its scribe, its compiler, or its commentator" [I, 14-15]) with the symbol for theology's efficient cause: the specific action of the Holy spirit, who searches out the secrets and the depths of God (see [I Co. 2:10]).8

The result is an overarching intersecting structure of the proemium's prologue and its questions. I now turn to each of these points individually in order to show that Bonaventure's deliberate knitting together of the symbolic and the scholastic produces a phenomenological method of "penetration" or perscrutatio that is probably unique to theology, and whose specific and exemplary character will be definitively demonstrated only when it takes root in the theologian's affectus.

\section{THE MATERIAL CAU SE, OR GOD AS THEOLOGY'S SUBJECT}

\section{A. The Intersecting Structure's D ynamism}

As with the symbolic interpretation of theology (huius libri vel theologiae), the symbolic interpretation of the four books of the Sentences by means of their material cause (causa materialis) begins to take shape along lines suggested by the epigraph drawn from the Book of Job. 9 The classification in accordance with the allegory of the four rivers that water the garden of Eden, a garden still untouched by sin (Gen. 2:11-14), is both exegetical and dynamic. (a) Pishon-etymologically the "movement of the mouth" (oris mutatio) - is that from which word and breath emerge simultaneously, just as the Son and the Spirit emanate from the Father (Book I, Trinity). (b) Gihon- "sand" (arena) - is what cannot be counted, just as it is impossible to count the innumberable created things (Book II, Creation). (c) Tigris- "arrow" (sagitta) - is the indivisible unity of iron and wood used to overcome the enemy, just as Christ, indissolubly both Man and God, vanquishes the enemy with his cross (Book III, Incarnation). (d) Euphrates- "the fecund one" (frugifer) - is what purifies the river and frees it of its alluvia, just as the sacraments restore us and free us from our sin (Book IV, Sacraments). 10

8. Note the intersecting structure of the symbolic reading (Sent. proem. I, 1-6) and the scholastic reading (Sent. quaest. proem. I, 6-15) in the determination of the four causes of this book or of theology (huius libri vel theologiae).

9. Sent. quaest. proem., q. $1(1,6)$.

10. Sent. proem. $(I, 3)$. On the etymological meanings of the rivers' names according to St. Jerome, see E. Gilson, Les idées et les lettres (Paris: Vrin, 1932), pp. 159-64 (cited by Ménard, “Une leçon inaugurale," p. 277, n.10). 
In keeping with the rule that symbolism connects (sum-bolon) things that have been, perhaps wrongly, separated and divided (dia-bolon) in a dry academic theology, Bonaventure here juxtaposes divine attributes with particular characteristics of a river ( since a watercourse, considered in various respects, gives us just the sensory images we need to begin to fathom (perscrutare) the secrets and the depths of God):11

(1). The trinitarian emanation: a river, whose current is unstoppable, allows us to see a reality that is as enduring as the eternal substance (Book I).

(2). The extent of creative power: a river's breadth from bank to bank shows how the Creator's attention reaches in its entirety to all $\mathrm{H}$ is creatures (Book II).

(3). Circularity and completeness: a river, which flows from its source to its mouth and returns again meteorologically to its place of origin, stands for the incarnate Word where Alpha and O mega coincide (Book III).

(4). Purity and liberation: a river, which cleanses the surrounding land as its floods receed, shows how the sacraments purify and deliver us so that God grants us salvation through them (Book IV). 12

Emanation, extent, circularity, and purity: for Bonaventure, these are in fact the divine attributes by which the internal dynamism of any authentic theology expresses itself. This is more than a simple classification of the material, the sort of classification that has been accused, often mistakenly, of hiding behind a kind of superficial symbolism.

\section{B. A False Accusation: "A Mania for Classification"}

Thus, it seems to me a mistake to criticize what H enri de Lubac hascalled the "artificial" or even "tiresome" character of Bonaventure's classifications.13 Our discomfort with this so-called "mania for classification" in fact shows nothing more than our own misunderstanding of both Bonaventure's symbolism and its enrichment of scholastic discourse. Far from being an attempt to establish a simple horizontal structure of correspondences, symbolism in Bonaventure in fact always stretches, in addition, along the dynamic axis of a

11. On the symbol (sumbolon) as act and locus of recognition as opposed to separation and division (diabolon), see F. M arty, Signe, symbole, sacrements, in R evuedes Sciences Religieuses, 1987, p. 225 n.75: "Le symbole est, dans la signification première du terme, le fragment de tessère, signe de reconnaissance par la possibilité de le faire coïncider avec un celui dont un autre est possesseur."

12. Sent. proem. $(I, 2)$.

13. Henri de Lubac, Exegèse médiévale: les quatre sens de l'Écriture (Paris: Aubier, 1964), IV:270 (II, 2): Speaking of Bonaventure, he says, "Avouons que, par leur caractère artificiel, par l'accumulation des divisions et des subdivisions tripartites, ses exposés sont souvent fatigants" (emphasis added). 
vertical correspondence that makes one ascend step by step, as if by degrees, toward intimate union with God.14 Thus, it is only because the subject matter of the river (the symbolic reading) always points toward the subject matter of theology (the scholastic reading) that the two are definitively and indissolubly linked. The only possible theological means of exposition for Bonaventure, therefore, is one that deliberately allows itself to flow into the symbolic dynamic that is proper to it, thereby testing from the very beginning the depth of the course that it still must run.

\section{THE FORMAL CAUSE, OR THE THEOLOGIAN'S MODUS PERSCRUTAT ORIUS}

\section{A. The D escent to the D epths: The Theological "Dive"}

Aside from its material causality, the river's depth in this respect-like an image made from an archetype or like theology in its mysteries-traverses a distance, the distance of its course, the specificity of which is never exhausted, even as the river traverses it. $15 \mathrm{M}$ oreover, in the formal determination (causa formalis) of the Book of Sentences, or of theology, this depth presents itself (or, better, hides itself) as something to be fathomed: cum igitur quatu or sint fluvii, quatu or sunt fluviorum profunda praedictis fluviis corre spondentia.16 Throughout his writings, Bonaventure insists on this dimension of depth (profunditas) as the very thing that simultaneously reveals and veils the divine mystery, which remains hidden and which it is the theologian's task to bring to light. 17

14. On the sense and the originality of Bonaventure's symbolism, in its double connection with creation and Scripture, see especially the recent study by Marc O zilou, La théologie symbolique, in L'œu vredes six jours (trans. of the H exameron), (Paris: Cerf, 1991), intro., pp. 29-44.

15. On the theological sense of the distance/ depth relationship, see J-L Marion, L'idole et la distance (Paris: Grasset, 1977), par. 19, pp. 283-309 (the fourth dimension, biblio/ essai). For the image/ archetype relationship (not symmetrical to the preceding), see L'idole, par. 1, pp. 15-24 (on the image). See also J-L Marion, Dieu sans l'être (Paris: PUF, 1982, 1991), chap. 1, pp. 15-37 (on the image and the archetype).

16. Sent. proem. $(I, 3)$.

17. One need only compare the prologues of the Breviloquium and the Soliloquium, with their respective openings, to the same passage from Ephesians (Eph. 3:14-19) in order to show that Bonaventure is grappling with the dimension of depth: "I bow my knees before the Father ... that you, being rooted and grounded in love, may have power to comprehend with all the saints what is the breadth and length and height and depth." In this way, both Scripture, in the development of its mystical senses (Breviloquium), and prayer, in the context of death and the Last Judgment, each receive a depth of their own (scriptural hermeneutic or the descent into hell). Aside from the repeating of the four dimensions (Eph. 3:14-19) at the 
Thus, the nature of the depth that the allegory of the four rivers examines here, the depth that is given exposition in the symbolic reading (proemium), and carried forward step by step in the scholastic reading (quaestiones proemii), is precisely this: on the one hand, we have the attributes of depth according to the four axes of the Sentences (Trinity, creation, Incarnation, and sacraments); on the other, we have the methodological imperative of a searching or penetrating approach (modus procedendi perscrutatorius) that answers the needs of the task of unveiling, a task required by theology (confounding one's adversaries, strengthening the weak, and reinforcing the righteous) 18

At the heart of this "penetrating approach" (or "searching of the depths") that Bonaventure's proemium to the Commentary on the Sentences calls for, precisely two things are joined (and in my view, paradoxically): the imperatives of contemporary phenomenology and the requirements of Bonaventuran theology. When speaking in a phenomenological mode, especially a Heideggerian one, to talk about "the depth" of some phenomenon is also necessarily to talk about its hiddenness at a depth that paradoxically reveals itself only in not showing itself (the phenomenology of the "non-apparent"). 19 Neither a duplicate nor a stand-in, the phenomenon, in the Heideggerian sense of the term (and according to the famous definition from Sein und Zeit) "to let that which shows itself be seen from itself in the very way in which it shows itself from itself." 20 This H eideggerian determination of the phenomenon, characterized (according to Jean-Luc Marion) first and foremost "by its unapparentness" or as "the rise to visibility of the not-yet visible," is already at play-paradoxically and as if in advance of itself-in the depths of the river that, according to Bonaventure, are to be searched.21 The phenomenon, in its non-appearance or hiddenness ( $<a>$-lêtheia), and the river in its depths or abysses (profunda fluviorum scrutatus est) have no other goal than to "show themselves" (phainesthai) or to come into the light (et abscondita produxit in lucem).

Just as Heidegger says that one needs phenomenology "because the phenomena are proximally and for the mot part not given," Bonaventure

beginning of each prologue, on the dimension of depth see respectively Brev., prol., par. 4 (V, 205-6) (French translation in the Franciscan edition, pp. 105-11), and Sol., prol., par. 2 (VIII, 28) (French translation in V-M. Breton, Saint Bonaventure [Paris: Aubier, 1943], pp. 276-77.)

18. Respectively Sent. proem. (I, 3-4) and Sent. quaest. proem., q. 2 (I, 10-11).

19. See fn. 60 and 61 below.

20. Heidegger, Sein und Zeit, par. 7, p. 34 (German pagination). English trans. by John MacQ uarrie and Edward Robinson (New York and Evanston: H arper \& Row Publishers, 1962), p. 58.

21. J-L. Marion, Reduction and Givenness: Investigations of $\mathrm{H}$ usserl, $\mathrm{H}$ eidegger, and Phenomenology, trans. Thomas A. Carlson (Evanston, Illinois: N orthwestern University Press, 1998), pp. 58-59. 


\section{EMMANUEL FALQUE}

will also say that one needs theology because proximally and for the most part the mystery is not immediately given by itself, or else is given at such a depth that it is the theologian's main task, with the aid of the Holy Spirit, to search it out or to penetrate it ( scrutare).22 According to one argument, this is where the strongly phenomenological character of the verse from Job comes from - the verse Bonaventure deliberately places as the epigraph to his proemium and under the aegis of which I believe his entire theology unfolds: profunda fluviorum scrutatus est, et abscondita produxit in lucem (Job 28:11). 23

\section{B. The A bysses of Theology}

Thus, in this symbolic investigation of theology's formal cause, there are for Bonaventure four characteristics of depth which, on the one hand, span the infinite distance separating the creature from its Creator and, on the other hand, sound the Creator's unreachable depth. The first characteristic is the sublimity of the divine being, which is hidden in the river of its eternal emanation whose depth remains beyond the reach of any judgment that seeks to circumscribe it (profundum aeternae emanation is est sublimitas esse divini ... Vere iudicia incomprehensibilia, quia profunda).24 The second characteristic is the emptiness of creatures who are cast into the river of the created world so that they sink of their own weight in the depths of sin (profundum creation is est vanitas esse creati ... Creatura enim quanto magis evanescit, tanto magis in profundum tendit, sive evanescat per culpam sive per poen am). 25 The third characteristic is the boundless, bottomless merit of the humanity of Christ who, in the river of his incarnation, achieved our redemption in his kenosis ( profundum incarnationis est meritum humanitatis Christi, quod tantum fuit, ut vere possit dici profundum, quasi non habens terminum nec fundum). 26 The fourth and last characteristic is the perfect efficacy of the healing found in the river of the sacramental economy, a healing that frees us and cures us completely, surpassing the bounds arbitrarily set by our salvation (profundum sacramentalis dispensationis est efficacia perfecti medicamenti. Tanta enim est efficacia medicinae sacramentalis, quod humanam mentem excedit, ut vere profundum possit dici). 27 Thus,

22. Heidegger, Sein und Zeit, p. 36; Eng. trans. p. 60.

23. Bonaventure, epigraph to the Commentary on the Sentences $(I, 1)$. On what is hypothetical and what well-established in such a phenomenological interpretation of Bonaventure, the reader is referred to my study, "Vision, excès et chair, essai de lecture phénoménologique de l'oeuvre de saint Bonaventure," Revue des sciences philosophiques et théologiques 79, no. 1 (1995), pp. 3-48.

24. Sent. proem. $(I, 3)$.

25. Sent. proem., $(I, 3)$

26. Sent. proem., $(I, 4)$

27. Sent proem., $(I, 4)$. 
four abysses open up for the theologian who, like a spelunker or a diver, strives to descend into them: the abyss of the divine being (Book I), the abyss of the condition of the creature (Book II), the abyss of the Incarnation (Book III), and the abyss of salvation (Book IV).

The author of the Sentences, a pioneer in his genre, does not fail, as Bonaventure sees it, to investigate these hitherto little-explored or unexplored depths: et hoc profundum perscrutatur magister in primo libro ... . in secundo libro .... in tertio ... in quarto libro.28 Perscrutatio which means "the action of uncovering, searching out, penetrating, or fathoming," thus emerges as the most appropriate theological method for allowing the depth of the mystery to unveil itself without destroying it.29 Like the "seeker of pearls"-a term applied since Augustine's Contra Faustum to religious men who search the Holy Scriptures (religiosis perscrutatoribus divinarum litterarum) - the theologian sent by the $\mathrm{H}$ oly Spirit thus strives, for his part, to descend to the bottom of the Christian mystery, opening it jewel case only in order that its most beautiful gems may shine in their own right in all their splendor. 30 Once again, just as Heideggerian phenomenology requires one to fathom or penetrate the phenomena (ergründen), and not to use them as the foundation for some architectonic (begründen), the Bonaventuran theological act here becomes a boundless, bottomless penetration into the mystery (perscrutatio) - even though, paradoxically, this happens only at the beginning of a commentary on a summa, one which often appears to be motivated by a purely constructive agenda. 31

28. Sent. proem., (I, 3-4). The same phrase is repeated four times.

29. F. Gaffiot, Dictionnaire latin-français (Paris: 1934), s.v. perscrutator (perscrutari).

30. See A. Blaise, Dictionnairelatin-fran çais des auteurs chrétiens (Paris: 1967), s.v. perscrutator: "chercheur de perles." For the use of the term to designate the theologian, or rather religious men reading the Scriptures, see Augustine, Contra Faustum $M$ anichaeum, French trans. in $\mathbb{E}$ uvres complètes de saint Augustin (Peronne, Ecalle, Vincent, Charpentier, Barreau) (Paris: Vives, 1870), vol. 25, L.III, chap. 3, p. 492 (on the double genealogy of J oseph in Matthew's and Luke's Gospels):

Il a donc été facile aux scrutateurs religieux des divines lettres (facile fuit ergo religiosis perscrutatoribus divinarum litterarum) de considérer les choses avec un peu de soin, et de voir par les deux généalogies décrites par les deux Évangélistes, que Joseph a pu avoir deux pères, dont la série d'aïeux s'est trouvée différente... Mais ces hommes, en étudiant toutes les parties de ces récits, ont cherché et trouvé bien d'autres choses encore (alia etiam quaestia et inventa sunt), mais elles sont par trop éloignées de votre intelligence.

31. Heidegger, Identité et différence, la constitution onto-théologique de la métaphysique (1957), in Qu.I (Paris: Gallimard, 1968), p. 292 n.1: “Ergründen (approfondir): sonder, atteindre le fond par sondage. Begründen: fonder en raison, donner une assise à . . . , justifier ce qui est déjà par retour à ce qui a été fondé." 


\section{EMMANUEL FALQUE}

\section{Perscrutatio et inquisitio}

The symbolic exposition (in the proemium) of the formal cause of the Book of Sentences, or of theology, is related to the scholastic treatment (in the quaestiones proemii) in this way: the letter explains from a methodological point of view what the former explores under the form of symbols (the four depths) (secundo quaeritur de causa formali sive modo agen di. Et dictum est, quod est perscrutatorius et in quisitivus secretorum). 32 Referring specifically to his own symbolic reading of theology's formal cause (et dictum est), the act of fathoming the depth of the mystery (modus perscrutatorius) will bend to the rules of the school only insofar as this does not mar the wisdom of its penetration or its unveiling. 33 In the second question of the proemium this modus perscrutatorius ( here, theological in its order but phenomenological in its gestures) is strangely placed next to other determinations of theology that are ratiocinative, indeed foundational in the sense of grounding something architectonic (begründen) : modus agen di est perscrutatorius et in quisitivus secretorum 34 / modus perscrutatorius sive ratiocinativus 35 / modus ratiocinativus sive inquisitivus 36 / modus in quisitivus. ${ }^{37}$ Thus, perscrutatio is not only a penetration of the mystery (modus perscrutatorius) but surreptitiously also comes to designate an inquiry or examination (modus inquisitivus), indeed a method of reasoning or calculating (modus ratiocinativus). There are so many assimilations here that no definition of the modus perscrutatorius contains or suggests them all. Could it be the case that any transition from the symbolic to the scholastic must be content with a radical rupture between the genres, as if the one could not be translated into the other? It could unless (and this would be characteristic of Bonaventuran mystical theology) the scholastic expresses the symbolic only in departing in a certain way, from the very start, from the forms imposed by the schools.

Without extolling a mystical anti-rationalism that would be absurd to attribute to Bonaventure, perhaps one can still discover the traces of another mode of rationality, purely theological in nature, in the fact that he presupposes the fathoming of the four dimensions that we have already

32. Sent. quaest. proem., q. 2, concl. $(1,9)$.

33. The Quaracchi Fathers rightly underline this link established by Bonaventure himself between his scholastic and symbolic readings of the formal cause of theology: "et dictum est, scilicet in proemio" (I, 9 n.1). At the same time, the connection that they establish in the same note between the modus perscrutatorius and the modus ratiocinativus or rationalis does not go without saying, as far as I am concerned ( "perscrutatorius, id est rationativus sive rationalis," (I, 9 n.1)). Even though there are traces of such an equation in Bonaventure, it could only happen at the expense of a radical transformation of the status of ratio, which would have to be modeled on the properly theological scheme of perscrutatio.

34. Sent. quaest. proem., q. 2, concl. $(I, 9)$.

35. Sent. quaest. proem., $(1,10)$.

36. Sent. quaest. proem., $(I, 10)$.

37. Sent. quaest. proem., $(I, 11)$. 
seen of the depth of the mystery: the sublimity of the divine being, the vanity of created things, the merit of Christ's humanity, and the perfect efficacy of the sacrament. 38 Aside from the statement of the conclusion (to justify its conciseness one can only cite the methodological imperative), the modus perscrutatorius that is characteristic of the Bonaventuran theological gesture is in fact never linked with the modus inquisitivus or the modus ratiocinativus in the development of this second question of the proemium. Thus, even if the modus inquisitivus is still sometimes linked to the modus ratiocinativus in order to define the theological rationality of his determinations ad extra (ad confundendum adversarios, ad fovendum infirmos, ad delectandum perfectos), 39 only the modus perscrutatorius gives meaning to the theological penetration of the mysteryad intra (quod ergo obiicitur in contrarium, dicen du m qu od omn es illae au ctoritates intelligun tur de perscrutation e curiosa, non de perscrutation e studiosa). .40 This is a warning to those who make use of the modus perscrutatorius out of curiosity and not in a diligent, careful way.

As is often the case in Bonaventure's scholastic texts, it is appropriate here to distinguish between the explicit intention of the discourse (a method of rationality for confounding one's enemies, strengthening the weak, and giving joy to the righteous) and the implicit search for a new theological attitude, as humble as the symbolic quest but still as rigorous as scholastic exposition. The result is the ultimate determination of the subject of theology (subiectum) as a passage or crossing over from the credible to the rational. In the proemium, this is always accomplished from the unique perspective of the joining of the symbolic and the scholastic:

subiectum theologiae, ad quod omnia reducuntur sicut ad totum universale. . . possumus et unico vocabulo nominare; et sic est credibile prout tamen credibile transit in rationem intelligibilis, et hoc per additionem rationist; et hoc modo, proprie loquendo, est subiectum in hoc libro. 41

The theological descent into the depths of the four rivers, drawn from the proemium's symbolic reading, thus begins from this point in accordance with the method of penetration (modus perscrutatorius) found in the scholastic reading, a unique theological method capable of supporting this sort of dive into mystery without either destroying the mystery or priding itself on the discovery of it. The theologian who is a perscrutator, or a treasure hunter-like the seeker of pearls-fathoms the unsuspected depths of the divine mystery (perscrutatio profundorum), searches out its inmost hiding places (abscondita), and reveals its most beautiful jewels ( revelatio): ex perscru-

38. Sent. proem. (I, 3-4). For the development of these four dimensions of depth, see above.

39. Sent. quaest. proem., q. 2, concl. $(1,11)$.

40. Sent. quaest. proem., q. 2, ad. 1.2.3 (I, 11).

41. Sent. quaest. proem., q. 1 , concl. $(1,7)$. 


\section{EMMANUEL FALQUE}

tatione autem profundorum in quatu or libris elicitur finis, scilicet revelatio quatuor absconditorum. 42 Like phenomena, which, as I have noted, "proximally and for the most part are not given" in phenomenology, the mystery thus somehow always remains veiled in theology and now needs to be manifested, no longer only according to the imperatives of a ratiocinative reason (modus ratiocinativus sive inquisitivus), but especially starting from the new requirements of a penetrative rationality (modus perscrutatorius). 43

\section{The D epths of the D escent: The Divine Secrets}

The dive into a depth, however, does not hesitate the discovery of its mysteries or secrets: the descent into the depths does not yet equal the depth of the descent. Once again, what keeps itself hidden or withdrawn must be allowed to reveal itself. Recall the depths of the rivers that Bonaventure deciphered in the symbolic reading of the proemium: the sublimity of the divine being (the river of the Trinity, Pishon), the vanity of created things (the river of creation, Gihon), the merit of Christ's humanity (the river of the Incarnation, Tigris), and the efficacy of the remedy (the river of the sacramental economy, Euphrates). Bonaventure aligns four hidden mysteries (sacramentum absconditum) with these four depths, like so many holy secrets (sacrum secretum), which the Holy Spirit, the only true perscrutator (I will return to this point), makes apparent and helps the theologian to reveal or to manifest: Spiritus sanctus enim est perscrutator secretorum et profundorum ... Magister etiam, spritu adiuvante, factus est revelator absconditorum. 44

The true God, or the hidden God (Deus absconditus), thus holds in the deepest recesses of his hiding place, both in himself and in his works, four secrets or hidden things (abscondita), which the Lombard, as a discoverer or pioneer assisted by the Holy Spirit, "brings to light" (produxit in lucem), "makes manifest" (manifestat), or, better, "allows to become manifest on their own" (manifestatur, repeated twice) .45

The first secret and first manifestation is the grandeur of the divine substance: primum abscon ditum est magnitu do divinae substantiae. 46 When God in himself (Deus in se) irradiates something with his trinitarian grandeur, it is then left to the theologian to search it out or penetrate it (perscrutatio), insofar as he first allows himself to be inhabited by the wisdom of God, which alone brings all things to light: vere magnitudo divinae substantiae est abscondita ... Certe nullus potest intueri, nisi ille, cum quo sapien tiae Dei inhabi-

42. Sent. proem. $(1,4)$.

43. Sein und Zeit, p. 36.; Eng. tr. p. 60.

44. Sent. proem. $(1,5)$.

45. Sent. proem. $(1,5)$.

46. Sent. proem. $(1,5)$. 
tat . . . H oc absconditum M agister, repletus sapientia de supernis, per primi libri perscrutationem produxit in lucem. 47

The second secret and second manifestation is the order of divine wisdom: secundum absconditum est ordo divinae sapientiae. 48 To discover this hidden order is to apply this theological method of penetration or perscrutatio (modus perscrutatorius), no longer only to the depth of God in himself, but to the depth of God hidden in his created works (Deus in operibus suis), in which and by which he justly manifests his wisdom: ut (ordo divinae sapientiae) cognoscatur, in diget perscrutatione profunditatis non in se, sed in operibus, in quibus ipsa reluce. . . H oc igitur absconditum manifestat $M$ agister in perscrutatione secundi. 49

The third secret and third manifestation is the strength of the divine power (tertium absconditum est fortitudo divinae potentiae). 50 Far from human power, such strength dissimulates itself again, but this time under the cloak of the weakness of Christ hanging on the wood of the cross: loquitur de Christo pendente in cruce, ubi latuit fortitudo virtutis sub pallio infirmitatis. $51 \mathrm{God}$ on the cross covered with the arms of our weakness (indu tus est armis nostrae infirmitatis) - for Bonaventure this is the great hidden mystery of Christianity (sacramentum absconditum) and its most holy secret (sacrum secretum). Indeed, such a thing had never before been heard (quod est inauditum a saeculis): the unheard-of mystery of a God taking on human weakness, allowing himself to be seen in an unimaginable way: as a visible God suffering in hisflesh. $52 \mathrm{H}$ ere, once again, it is the job of the theologican and his modus perscrutatorius to allow this paradoxical hidden mystery to become manifest through him-the mystery of the triumph of divine power in human weakness: in perscrutation etamen tertii libri, ubi ostenditur, quod Christus in sua infirmitate vicit con trariam potestatem, manifestatur for titu do divinae potentiae. 53

The fourth and final secret and manifestation is the sweetness of divine mercy: quartum absconditum est dulcedo divinae misericordiae 54 Again hidden in the deepest recesses of God's heart, it nevertheless remains visible to the eyes of those who fear $\mathrm{H}$ im (vere abscondita et reservata timentibus), bursting into full light in the remission of sins, the healing of wounds, and the conferring of final reward. $55 \mathrm{M}$ oreover, the theologian must allow this same

47. Sent. proem. $(1,5)$.

48. Sent. proem. $(I, 5)$.

49. Sent. proem. $(I, 5)$.

50. Sent. proem. $(1,5)$.

51. Sent. proem. $(1,5)$.

52. Sent. proem. $(I, 5)$.: hoc est sacramen tum abscon ditum, sacrum secretum, qu od Deus fortis, ut hostem vinceret, in du tu s est armis nostraeinfirmitatis; qu od est in au ditum a saeculis.

53. Sent. proem. $(1,5)$.

54. Sent. proem. $(1,5)$.

55. Sent. proem. $(I, 5)$.: nam viso, qualiter Deus dimittit peccata in praesenti, et qualia nostris vulneribus adhibet medicamina, et qualia in futuro dabit praemia, nobis dulcedo divinae misericordiae aperitur. 


\section{EMMANUEL FALQUE}

ineffable sweetness of the divine mercy to reveal itself through him in accordance with the method proper to his penetrative theology (modus perscrutatorius) : haec dulcedo manifestatur in perscrutatione quarti libri. 56

\section{E. From Withdrawal to Manifestation}

The grandeur of the divine substance in the Trinity, the order of wisdom in its works, the strength of its power under the cloak of human weakness, the sweetness of its mercy towards those who fear it: these are the four secrets or hidden treasures (abscondita) that the theologian must allow to manifest themselves through him. He must therefore dive into the depths of the river of the divine emanation (sublimity of the divine being), the river of creation (vanity of created things), the river of the Incarnation (Christ's merit), and the river of the sacramental economy (efficacy of the remedy). Thus, in the same way that "behind the phenomenon of phenomenology there is essentially nothing else; on the other hand, what is to become a phenomenon can be hidden," likewise there is nothing of God or in God that can manifest itself outside these four broad categories: his substance, his wisdom, his power, and his mercy-even though in this as in other things, he withdraws into his own inmost depths. 57 What the method of theological penetration (modus perscrutatorius) reveals and respects is not so much God himself in his ontic attributes as his manner of being or his style: a presence that imposes itself ( manifestation) only insofar as it has itself at its own disposal (withdrawal). In contrast to all the gnoses that have been legitimately denounced since the first Christian centuries, there is here neither duplication nor substitution where the being and the appearance of God are concerned. Nonetheless, God's being can never be reduced to his appearance alone. Jean-Luc Marion, speaking more as a phenomenologist than as a theologian, emphasizes that

depth here does not indicate that 'behind' the phenomenon something else would be waiting to appear, but that the very appearing of the phenomenon - as a way (of Being) and therefore as a nonbeing-reveals a depth. The depth does not dub or betray (double) the phenomenon (in the cinematographic or detective sense of doubler); it reveals it to itself. 58

At present, in a primarily medieval and scholastic project, the important question is not whether such a phenomenology deserves the title "phenomenology of the unapparent," given to it by Heidegger as he later

56. Sent. proem. $(I, 5)$.

57. Heidegger, Sein und Zeit, par. 7, p. 36; Eng. trans. p. 60.

58. J-L Marion, Reduction and Givenness, p. 63. 
reread Sein und Zeit.59 For present purposes, let me simply note that, in Bonaventure, the act of the manifestation of God seems to correspond closely, point for point, to the double requirement of the depth of the Heideggerian phenomenon: (a) the showing of the phenomenon on its own initiative, since God alone reveals himself and does so on his own initiative, in a wisdom in which the theologian allows himself to dwell (nullus potest intueri, nisi ille, cum quo sapientia Dei inhabitat), and (b) the manifestation not of the surface of what is "manifest" (H usserl's "flat phenomenon") but of what is "non-manifest" in that the mystery, like the phenomenon, always withholds itself from its own appearance, but without either substitution or duplication. 60

Asfor method, in order to carry out thisphenomenological reinterpretation of Bonaventuran perscrutatio, let me add that Bonaventure, as theologian, investigates the discovery of the depth of the divine mystery, using the modus perscru tatorius, just as $\mathrm{H}$ eidegger, this time acting as phenomenologist and using the aforementioned method of "stepping back" (Schritt zurück), digs into (ergründet) the soil around the tree of philosophy in order to free its roots. 61 The imperative of a manifestation of a phenomenon "from itself

59. Heidegger, Séminaire de Zähringen (1973), in Qu.IV (Paris: Gallimard, 1976) , p. 339 (Martinaeu's trans.). Traces of an argument of this sort can be found in Dominique Janicaud's recent work, L e tournant théologique de la phénoménologie française (Paris: L'éclat, 1991).

60. On these two characteristic traits of the depth of the Heideggerian phenomenon, see J-L Marion, Reduction and Givenness, pp. 57-59.

61. (a) For the metaphor of exploring or digging into the soil, see Heidegger, Q u'est-ce que la métaphysique, le retour au fondement de la métaphysique (1949), in Qu.I (Paris: Gallimard, 1968), p. 23:

Pour en rester à cette image (de l'arbre de la métaphysique de Descartes), nous posons la question: dans quel sol les racines de l'arbre de la philosophie trouvent-elles leur point d'attache? De quel fond les racines et par elles l'arbre tout entier reçcoivent-ils la vigueur et les sucs nourriciers? Quel élément celé dans le fond et le sol s'entrelace aux racines qui portent l'arbre et le nourrissent?

(b) For the method of stepping back, see Heidegger, Identité et différence (1957), in Qu. I, p. 284:

pour nous le dialogue avec I'histoire de la pensée n'est pas caractérisé par l'engloutissement (aufhebung), mais par le pas en arrière, ... Ces mots 'le pas en arrière' (Schritt zurück) ouvrent la porte à de multiples malentendus. Ilsne désignent pas une démarche isolée de pensée, mais un mode de mouvement de la pensée et un long chemin à parcourir.

(c) Finally, note the multiple occurrences of perscrutatio in this passage from Bonaventure's proemium $(I, 5)$, although he never uses modus inquisitivus or modus ratiocinativus. This clearly confirms, if confirmation were necessary, the hypothesis of the preeminence of investigation (ergründen) over foundation (begründen) in Bonaventure's theology. See Sent. proem, $(I, 5)$ : $\mathrm{H}$ oc absconditum M agister per primi libri perscrutationem produxit in lucem/in perscrutatione secundi/in perscrutatione tamen tertii libri/in perscrutatione quarti libr 
in the ver y way in which it shows itself from itself," which H eidegger imposes on phenomenology in the turn "to the things themselves" here becomes - in the same way but in a completely different order-the one that Bonaventure, paradoxically, imposes on theology-this time according to its final cause and always by virtue of the inalterable transition from the symbolic to the scholastic. 62

\section{THE FINAL CAUSE, OR THEOLOGY AS AFFECTIVE DISPOSITION}

\section{A. Toward a Practical Theology}

More than the places where something manifests itself (such as the four rivers of the material cause), more than the thing itself that is manifested ( such as the four secrets of the formal cause hidden in the depth of the four rivers and revealed by the exploratory, investigative theological method), the transition from the symbolic to the scholastic reading of theology's final cause (causa finalis) indicates, this time, the necessarily theoretico-practical aim toward which any theology that seeks the depths of things should tend, according to Bonaventure. Thus, just as the scholastic reading of theology's formal cause fixed the modalities of the modus perscrutatorius which alone can explore the depth of the rivers (quaestio 2), here the scholastic reading of the final cause likewise refers explicitly and primarily to its symbolic interpretation. It thereby traces the general outlines of a theological, theoretico-practical habitus which alone makes manifest the secret hidingplaces (abscondita) of the divine mystery (quaestio 3): tertio qua eritur de causa finali. Et cum dictum sit, quod liber iste est ad revelandum abscondita, quaeritur, u trum opus hoc sit contemplation is gratia, vel ut boni fiamus. 63

With regard to this imperative of unveiling (revelandum), does Bonaventuran theology thus define itself principally in a theoretical quest that receives its grace merely from speculation (scientia speculativa)? Or, by contrast, does it lean more toward the practical side so that by it we may achieve the very thing toward which theology guides us (scientia practica)? Following Francis, his brother and spiritual master, Bonaventure deliberately opts for the latter solution in preference to the former: et pro fine scientia theologica habet tum contemplationem, tum ut boni fiamus, et quidem principalius, ut boni fiamus. 64

62. Sein und Zeit, p. 34; Eng. tr. p. 58.

63. Sent. quaest. proem., q. $3(1,12)$.

64. Sent. quaest. proem., q. 3, concl. $(1,13)$. 


\section{B. The Affect: The Indissoluble U nity of Theory and Practice}

Bonaventure's originality, meanwhile, does not display itself only in this explicit formulation of the primacy of the practical over the theoretical, a fairly common principle since Augustine. Rather, it expresses itself more implicitly but no less clearly in his intention to articulate theory and practice together in a unique theological habitus specifically designed to justify the good that is based on the theologian's modus perscrutatorius: Scientia theologica est habitus affectivus et medius inter speculativum et practicum. 65 Considered in itself (in se), our intellect reaches its perfection in accordance with the grace of speculation. When extended to its works (extendi ad opus), however, it pushes us all the more, by contrast, to do good, thus establishing the rules of a purely practical knowledge. But in connection with affectus (extendi ad affectum), our intellect paradoxically joins the theoretical to the practical in a single wisdom (sapientia) and expresses their union thus: extendi ad affectum, (intellectus noster) sic perfecitur ab habitu medio inter pure speculativum et practicum, qui complectitur utrumque; et hic habitus dicitur sapientia quae simul dicit cognitionem et affectum. 66

The affectus that the theological habitus here depends on, thus uniting theory and practice, designates not "affectivity" in the modern psychological sense of a subject modified in its internal sensibility, but rather the "affective power" or the "desire of the heart" inspired by the object toward which it moves. 67 A power or faculty of this sort holds theory and practice together insofar as it does not attend to practice or morality alone but directs itself toward all the dispositions required by the subject (habitus), whether or not the subject is a theologian putting into practice a theory initially required for the benefit of salvation. Hence, Bonaventure again takes up affectio or affectivity in the Bernardian sense of the term, according to which the spirit loves by means of its intelligence only that which it already believes and desires by faith: miro enim modo anima delectatur in in telligen do qu od perfecte fide credit. Unde Bernardus: "nihil libentius in telligimus, quam quod iam fidecredimus" (De. consid., L. V, c. 3).68

65. Sent. quaest. proem., q. 3, concl. $(1,13)$.

66. Sent. quaest. proem., q. 3, concl. $(1,13)$. Within the concept of wisdom, Bonaventure here unites cognitio and affectus, rather than cognitio (theoria) and moralia (practica). This shift from moralia to affectus can most plausibly be explained by the citation from Ecclesiasicus that follows this text and according to which wisdom is to be understood first of all in its etymological sense of scientia sapida (Eccl. 6:23: sapientia en im doctrinae est secundum nomen eius). Even if the taste or flavor of wisdom makes it seem to have more in common with affectus, it is still the case that from the moment it first appeared, affectus, in its mode of being, unites first of all the two dispositions of the intellect (theoretical and practical) rather than itself exclusively constituting one of the branches.

67. See L exique saint B onaventure (Paris: Éditions franciscaines, 1969) , S.v. affectus, p. 15.

68. Sent. quaest. proem., q. 2, concl. $(1,11)$. 


\section{EMMANUEL FALQUE}

The new rationality that is probing rather than foundational, the rationality eagerly pursued by the modus perscrutatorius, thus finds in the Christian imperative of love (amor) not only a collection of practical prescriptions or commandments but also and primarily a properly Christian type of rationality - one that is alone in being able to produce true consolation (solatium) without stifling the merit of the human quest: sed quando fides non assentit propter rationem, sed propter amorem eius cui assentit, desiderat habere rationes; tunc non evacuat ratio humanam meritum, sed auget solatium. 69

\section{Affect and Affection}

Thus, in its final determination (causa finalis), this introduction to or inaugural lecture (proemium) in the Commentary on the Sentences might seem to be St. Bonaventure's "discourse on method" in that it redirects the novelty of its approach (the modus perscru tatorius) toward the internal disposition of the subject, which alone can explain it (the affectus as a theological habitus that unites theory and practice in the movement of the will and the desire manifested by love). In this respect, it is especially regretable that what is probably still one of the best interpretations of this text, that of $A$. M énard, discusses neither the originality of the Bonaventuran modus perscrutatorius nor its specific roots in the theologian's affectus. 70 Bonaventure's original contribution, I believe, lies not only in having forged an original theological method, eminently dialectical and unifying (the coincidentia oppositorum), but much more in having modified the very status of rationality by turning love (amor) into a conceptual determination at the junction of theory and practice. He thereby explains how any method can properly be called theological.

Any strictly theo-logical truth, one that has its roots in God, will no longer be content with its unique objective determination. On the contrary, such a truth will take on a performative sense, one that is transforming for the subject that states it, or it will not exist. Thus, although the mathematical proposition stating that the diagonal of a square is incommensurable with its side (diameter est asymeter caostae) might have no effect on the person stating it, the kerygmatic formula "Christ died for us" and similar things are quite different: they move us to love, unless we are hardened sinners (nam haec cognitio, quod Christus pro nobis mortuus est, et consimiles, nisi sit homo peccator et du rus, movet ad amorem). Because they come from the $O$ ne who alone is $L$ ove made visible even unto his death for us ( pro nobis), knowledge through love is the only thing that puts in motion (movet) whoever comes to know them. ${ }^{71}$

69. Sent. quaest. proem., q. 2, ad. $6(1,11)$.

70. See A. Ménard, "Une leçon inaugurale de Bonaventure, le Proemium du Livre des Sentences," Études franciscaines (1971) : 273-98.

71. Sent. quaest. proem., q. 3, concl. $(1,13)$. 
Always remaining speculative in order to engender a practice, the strictly theological rationality of the modus perscrutatorius rooted in affectus thus detaches itself definitively from any uniquely and purely speculative conceptual determination.

Setting aside the problem of anachronism and picking up again the analogy with the Heideggerian circumscription of phenomenology, it is the same here with the theological habitus affectus in Bonaventure (scientia theologica est habitus affectivus) as with state-of-mind or Befindlichkeit in Heidegger. In both cases, affection is less a matter of a "psychology of moods" than a description of mood itself (Stimmung) as "being disposed" and a fundamental existentiale 72 Since the restricted scope of the present study makes oversimplification unavoidable, let me simply note here that both the habitus of the affectus in the one case, and the Stimmung of Befindlichkeit in the other, have the power to open up a world, each in its own distinctive way. ${ }^{73}$ For Bonaventure, this happens in accordance with the conceptual, theological determination of love; for H eidegger it happens in accordance with the purely humanist traits of fear and anguish. 74 We no doubt discover here the definitive gap (this time unbridgeable) that separates the astonished Franciscan theology of a Bonaventure from the anguished contemporary phenomenology of a Heidegger (or of the early H eidegger). This is a divide that only a Christian phenomenology of praise

72. Heidegger, Sein und Zeit, par. 29, p. 134; Eng. trans. p. 172-73 (Dasein as affection). In his french translation (Paris: Authentica, 1985), E. Martineau correctly notes in his index (s.v. Befindlichkeit, p. 310) that the determination of affection in Heidegger's conference on the concept of time (1925) is drawn originally from Augustinian affectio. Elsewhere, we find at least a trace of it in Heidegger's own citation of Augustine's Contra Faustum (Sein und Zeit, p. 139 n.1), in which Heidegger refers precisely to this type of knowledge through love. Thus, it is not surprising to see Bonaventuran theology and H eideggerian phenomenology flirting with each other here, each in its own way. Additional evidence comes from Heidegger's mention of Bonaventure side-by-side with Husserl, in his curriculum vitae: "outre la petite somme de saint Thomas d'Aquin et certaines œuvres de saint Bonaventure, ce sont les recherches d'Edmund $\mathrm{H}$ usserl qui furent décisives pour mon évolution scientifique" (curriculum vitae cited in $\mathrm{H}$. Ott, $\mathrm{M}$ artin $\mathrm{H}$ edegger: éléments pour une biographie, French trans. (Paris: Payot, 1990), pp. 90-92).

73. Heidegger, Sein und Zeit, p. 139; Eng. trans. p. 178-79:

A state-of-mind (B efindlichkeit) not only discloses Dasein in its thrownness ( . . . ), it is itself the existential kind of being in which Dasein constantly surrenders itself to the "world' and lets the 'world "matter" to it in such a way that somehow Dasein evades its very self ( . . .). Phenomenological interpretation must make it possible for Dasein itself to disclose things primordially; it must, as it were, let Dasein interpret itself.

74. Heidegger, par. 30 (Fear as a State-of-Mind). 
or joy would be in a position to bridge, if it is true that anguish cannot have the last word where being human is concerned. 75

\section{The Manifestation of God and the Transformation of the H uman Being}

From the point of view of the final cause, to command affectus and love to make manifest the still-invisible depth of God brings up the figure, original in Bonaventure, of a "manifest God." Bonaventure does this while preparing to comment on the Book of Sentences, a project that had been on his mind ever since his first theological studies. For his part, Peter Lombard, the master of the Sentences, had not failed to emphasize in hisprologue this aim of the manifestation of God that is specific to theological work. The Seraphic Doctor pays him homage for this elsewhere, albeit circumspectly, in his symbolic reading of the proemium: haec (revelare profunda et absondita) fuit intentio et finis M agistri, secundum quod ipse dicit in Prologo: "Iu cernam, inquit, veritatis in candelabro exaltare volentes." 76

Meanwhile, the Bonaventuran proemium, this time in its scholastic reading and at the heart of its theological determination of the habitus affectivus, will distinguish for itself-or, better, will get to the heart of-the sense of this Lombardian manifestation. The Lombard's theological intention remains purely speculative (speculativa); at least this is the charge Bonaventure levels against it in the first argument of the third quaestio: "M agister dicit in littera (in eius prologus), quod finis sive intentio sua 'est theologicarum inquisitionum abdita pandere'; sed hoc pertin et ad eum, cuius finis est speculatio." 77 The force of the objection isclear: Peter Lombard's theological quest unveils the hidden mysteries of the divine (abdita pandere) only insofar as it serves the cause of speculation (cuius fin is est speculatio), as the aim of hisB ook (of Senten ces) shows. In short, for the Lombard there is no theological habitus that is not first of all an ordinary mode of the purely abstract habitu s speculativus, like the intrinsically objective determinations of mathematical propositions.

To make the manifestation of God into a purely speculative act, Bonaventure says, creates a confusion, both practical and theoretical, between the goal of theology and its status. Whereas it is certainly part of the goal of theology to make God manifest, still such a manifestation is valuable only insofar as it remains oriented toward its only legitimate status - the encounter, through love, between God in his act of revelation and man in

75. Along the same lines, see for instance J-L. Chrétien, "La joie d'être," in La voix nue, phénoménologie de la promesse (Paris: de Minuit, 1990), pp. 275-94, which focuses mainly on Augustine, Thomas Aquinas, and Eckhart. See also J. Greisch, La parole heureuse: Martin H eidegger en tre les choses et les mots (Paris: Beauchesne, 1987), which also takes a H eideggerian tack but focuses on the late Heidegger.

76. Sent. proem. $(1,6)$.

77. Sent. quaest. proem., q. 3, arg. $1(1,12)$. 
his affective power: qu od obi icitur, quod est ad pandendum abscon dita; dicen dum, quod ibi non est status, quia illa revelatio ordinat ad affectum. 78 Thus, for Bonaventure, there is no revelation or manifestation of God that does not orient itself immediately and directly toward the experienced encounter of man and God-or, better, toward the experiential encounter, if the affectus, in its own way, can also be considered among existential things.

\section{THE EFFICIENT CAU SE, OR THE HOLY SPIRIT, THE "PERSCRUTATOR"}

\section{A. The Revealer of Hidden Mysteries}

Finally, in the ultimate determination of theology by its efficient cause (causa efficiens), the $\mathrm{H}$ oly Spirit manifests itself, in the symbolic reading of the proemium, as the one who principally performs in man the theological act of a descent (perscrutatio) into the secrets and depths of God. The Spirit alone is the principal perscrutator or discoverer of every theological truth: Spiritus sanctus enim est praecipuus perscrutator secretorum et profundorum. 79 As for the Lombard, the Holy Spirit consecrates him in turn, as it does every theologian, as a revealer or one who makes manifest (revelator) the mysteries that are still hidden in God: Magister etiam, spiritu adiuvante, factus est revelator abscon ditorum. 80 Once again, just as in phenomenology the phenomenon itself takes the initiative in its own appearing,81 in theology likewise (but in a different way), God alone decides to manifest in manifesting himself ( himself or in his works). ("Manifest" here has the double meaning of the "appearance" and the "pretense" for making himself known.) God thereby retains the complete liberty of his absolute power, even at his weakest.82 Thus, like the phenomenologist who, for his part, tries only to exhibit "an entity as it shows itself in itself," the theologian forgets himself in some sense in the act of God's self-manifestation in order that the mystery of God may rise up in him as God wishes to show

78. Sent. quaest. proem., q. 3, ad. $1(1,12)$

79. Sent. proem. $(1,5)$.

80. Sent. proem. $(1,5)$.

81. Sein und Zeit, p. 34, par. 7; Eng. trans. p. 58: "Thus phenomenology means to let ... that which shows itself be seen from itself in the very way in which it shows itself from itself."

82. It is precisely this absolute liberty of God's revealing himself by himself that the theologian Hans U rs von Balthasar attempts to translate and preserve in the theological concept of "objective evidence." See especially L a gloire et la croix (Paris: Aubier, 1965) , I:392: "I'évidence objective est une évidence qui émane et rayonne du phénomène lui-même et non celle qui a pour base la satisfaction des besoins du sujet." For my part, I prefer to use the term "manifestation of God," since such evidence of the divine has nothing truly objective about it, at least in the ontic and scientific sense of the term. 


\section{EMMANUEL FALQUE}

himself. 83 This goes beyond speculation alone and into the deepest parts of the theologian's affective power.

\section{B. Peter Lombard, A uthor of the Sentences}

The final scholastic reading of theology's efficient cause thus anoints the Lombard justly as the true author (auctor), with the Holy Spirit, of the Senten ces, and not merely its scribe (scriptor), its compiler (compilator), or its commentator (commentator).84 "Peter Lombard, the Bishop of Paris, is the author of this book" ( Petrus L ombardus, Episcopus Parisiensis, est auctor huius libri), not first of all in what he writes on his own (we know, on the contrary, how much he inherits directly from a tradition), but in the fact that his work is principally his own (sua tanquam principalia) and in reality draws on other authors only because they confirm (ad confirmationem) the same thing that the Holy Spirit inspires him with.85 Aliquis scribit et sua et aliena, sed sua tanquam principalia, aliena tanquam an nexa ad confirmation em; et talis debet dici auctor. 86 Therefore, every theological writer, and especially St. Bonaventure, has in this sense no other task than to allow to shine and sparkle in him (phain esthai) the unfathomable depth of the manifest God. Thus, in accordance with the modus perscrutatorius, which is the only appropriate type of rationality, he gives credit to the $\mathrm{H}$ oly Spirit, who inhabits him and remains, for both author and reader, the true and ultimate author (auctor) of his theology: Spiritus omnia perscrutatur, etiam profunda Dei (1 Cor. 2:10).87

83. Sein und Zeit, p. 35; Eng. trans. p. 59.

84. Sent. quaest. proem., q. 4, concl. (I, 14-15).

85. Sent. quaest. proem. $(1,14)$.

86. Sent. quaest. proem. $(I, 15)$

87. Cited by Bonaventure, Sent. proem. $(I, 5)$. 